Asian Pacific Journal of Reproduction

Journal homepage: www.apjr.net

\title{
Preservability of rabbit semen after chilled storage in tris based extender enriched with different concentrations of Propolis ethanolic extract (PEE)
}

\author{
Islam El-Sayed El-Seadawy ${ }^{1}$, Walid Said El-Nattat ${ }^{1 凶}$, Magda Mohamed El-Tohamy ${ }^{1}$, Samy Ali Hussein Aziza ${ }^{2}$, \\ Yakot Abdelfattah El-Senosy ${ }^{2}$, Ahmed Said Hussein ${ }^{3}$ \\ ${ }^{1}$ Animal Reproduction and A,I Dept., Veterinary Research Division, National Research Centre, Giza, Egypt \\ ${ }^{2}$ Biochemistry and Clinical Biochemistry Dept., Faculty of Veterinary Medicine, Benha University, Egypt \\ ${ }^{3}$ Food Industry Dept, Food Industry and Nutrition Research Division, National Research Center, Giza, Egypt
}

\section{ARTICLE INFO}

Article history:

Received 10 January 2017

Revision 20 February 2017

Accepted 27 February 2017

Available online 1 March 2017

Keywords:

Male rabbits

Semen extender

Propolis extract

Antioxidants

HPLC

\begin{abstract}
Objective: To maintain semen quality of male rabbits during chilled storage by enrichment the tris based diluent with different concentrations of propolis ethanolic extracts. Methods: Total phenolic and total flavonoid contents, as well as antioxidant activity was determined in propolis ethanolic extract (PEE). The extract was analysed by HPLC for separation and identification of target metabolites. Semen was collected from 10 rabbit bucks, pooled, then divided into five aliquots (each of $500 \mu \mathrm{L}$ ) and diluted each in $5 \mathrm{~mL}$ Tris-citric acid-glucose-egg yolk extender (TCGY). The 1st aliquot served as control while PEE was added at concentration of 0.8, 1.2, 1.6 and $2.0 \mathrm{mg} / 5 \mathrm{~mL}$ tris extender in the aliquot 2, 3, 4 and 5 respectively. Diluted semen samples were subjected to cooling at $4{ }^{\circ} \mathrm{C}$ for $72 \mathrm{~h}$. Sperm motility, sperm viability, sperm abnormality, sperm membrane integrity and acrosome integrity were evaluated in chilled semen allover the chilling period. Results: The resluts revealed presence of a considerable amount of total phenolic compounds (98.67 mg GAE/g extract) and total flavonoids (70.16 mg CE/g extract) which were parallel to an antioxidant activity assessed as ABTS, DPPH and FRAP (198.65, 180.18 and $306.17 \mathrm{mM} \mathrm{TE} / \mathrm{g}$ extract respectively). The dominant phenolic acid was chlorogenic acids $(3.959 \mathrm{mg} / \mathrm{g}$ extract). Other compounds were found in less amounts rosmarinic acid (3.959 $\mathrm{mg} / \mathrm{g}$ extract), myrcetin $(1.946 \mathrm{mg} / \mathrm{g}$ extract), kaempferol $(1.089 \mathrm{mg} / \mathrm{g}$ extract) and apeginin-7glucoside $(1.113 \mathrm{mg} / \mathrm{g}$ extract). Obtained results clearly demonstrated that the addition of 1.2$1.6 \mathrm{mg}$ PEE in the chilled extended rabbit semen proved to be beneficial for maintaining semen characteristics compared to control and the addition of 0.8 and $2 \mathrm{mg}$ PEE. Conclusions: The enrichment of rabbit semen tris-basic extender with 1.2-1.6 mg PEE/5 mL tris-extender (as the best and safe concentrations) maintain the sperm characteristics in good condition all over $72 \mathrm{~h}$ of chilling.
\end{abstract}

\section{Introduction}

Developing and improving methods for semen preservation would provide adequate fertility rates that maintain the high production rates for rabbit industry to be economically beneficial. Several studies had been conducted to improve the preservation protocols and the extender composition[1-10]. Unfortunately, rabbit

\footnotetext{
Corresponding author: Walid S El-Nattat, Animal Reproduction and AI Department, Veterinary Research Division, National Research Centre, Dokki, Giza. 12622, Egypt. Tel: +20 233371635 Fax: +20 237601877 E-mail: elnattat@gmail.com
}

spermatozoa had a restricted capacity to withstand the chilling[5,6] or frozen storage[11] is limited. This is partially due to the membrane lipid peroxidation caused by an excess level of reactive oxygen species (ROS), which in turn would affect lipids, proteins, nucleic acids and sugars within the sperm[12,13].

This is an open access article distributed under the terms of the Creative Commons Attribution-Non Commercial-Share Alike 3.0 License, which allows others to remix, tweak and buid upon the work non-commercially, as long as the author is credited and the new creations are licensed under the identical terms.

For reprints contact: reprints@ medknow.com

(C)2017 Asian Pacific Journal of Reproduction Produced by Wolters Kluwer- Medknow

How to cite this article: Islam El-Sayed El-Seadawy, Walid Said El-Nattat, Magda Mohamed El-Tohamy, Samy Ali Hussein Aziza, Yakot Abdelfattah El-Senosy, Ahmed Said Hussein. Preservability of rabbit semen after chilled storage in tris based extender enriched with different concentrations of Propolis ethanolic extract (PEE). Asian Pac J Reprod 2017; 6(2): 68-76. 
In folk medicine, fruits, vegetables and their seeds extracts exerted an ancient life secure for their high contents of remedies compounds[14,15]. Some of these extracts were used in animal semen preservation[16-18]. Their cryopreserving properties are a hidden meaning in their strong antioxidant capacity, that enabled spermatozoa to overcome the outside/inside damage during cryopreservation process[19,20].

Bees have been extensively employed for their products since ancient due to their miracle pharmacological activity[21]. Propolis or "bee glue" is one of the bee products that possess various biological activities such as antibacterial[22,23], antifungal and antiviral[24,25], anti-protozoal[26], anti-inflammatory[27], antitumor[28], immunostimulating[29] and antioxidant properties[30-32]. Propolis contains some minerals ( $\mathrm{Mg}, \mathrm{Ca}, \mathrm{I}, \mathrm{K}, \mathrm{Na}, \mathrm{Cu}, \mathrm{Zn}, \mathrm{Mn}$ and $\mathrm{Fe}$ ), some vitamins (B1, B2, B6, C and E) and a number of fatty acids. In addition, it contains some enzymes as succinic dehydrogenase, glucose-6-phosphatase, adenosine triphosphatase and acid phosphatase[33]. Propolis, also contains more than 300 biochemical constituents, including mostly a mixture of polyphenols, flavonoids, terpenoids, steroids, sugars, amino acids and others[34]. The antioxidant activity of propolis is mainly attributed to its flavonoid content, that is capable of scavenging free radicals and thereby it protects cell membrane against lipid peroxidation[35]. Propolis also induces the activation of antioxidant enzymes such as superoxide dismutase[36] and catalase[37] against free radicals.

Thence, the present study aimed to maintain semen quality of male rabbits during chilled storage by enrichment the tris based diluent with different concentrations of propolis ethanolic extracts to be used in chilling of the extended semen.

\section{Material and Methods}

\subsection{Collection of samples and chemicals}

\subsubsection{Propolis samples}

Propolis samples were obtained from colonies of honeybees located in Dakahlia Governorate, Egypt, in the summer of 2015. The sample was kept in the dark at $-20^{\circ} \mathrm{C}$ up to its processing.

\subsubsection{Phenolic acids standards}

Gallic, protocatechuic, gentisic, chlorogenic, vanillic, caffeic, syringic, p-coumaric, ferulic, sinapic, rosmarinic and cinnamic acid, catachine, scoplatine, rutin, naringeen, hisperdin, myrcetin, quercetin, apegnin and kaempferol were purchased from SigmaAldrich, Inc. (Louis, USA).

\subsubsection{Radical precursor and folin}

DPPH (2,2-Diphenyl-1-picryl-hydrazyl), ABTS (2,2-azino-bis/3ethil-benothiazoline-6-sulfonic acid), TPTZ (2, 4, 6- tripyridyl-striazine) and Folin-Ciocalteu reagent were purchased from Sigma-
Aldrich, Inc. (Louis, USA).

\subsubsection{Solvents and other chemicals}

Acetonitrile (HPLC grade) was purchased from Aldrich Chemical (GmbH \& Co KG, Steinheim, Germany). Petroleum ether, diethyl ether, ethyl acetate, tetrahydrofuran and methanol (analytical grade) were purchased from Tedia Company, Inc., Fairfield, OH 45014, USA. Other chemicals used in this study i.e. sodium hydroxide, potassium persulphate, dinitrosalicylic acid, aluminum chloride, sodium nitrite, sodium carbonate, hydrochloric acid, sulphuric acid and acetic acid were of analytical grade.

\subsection{Preparation of extract}

Ethanolic extract of propolis was prepared as described by Cvek et al.[38] with some modification by cutting $50 \mathrm{~g}$ of crude propolis sample into small pieces, grounded, extracted with $500 \mathrm{~mL}$ of $80 \%$ ethanol $(1: 10 \mathrm{w} / \mathrm{v})$ and stirred continuously by shaking incubator $(150 \mathrm{r} / \mathrm{min})$ in the absence of light at room temperature for a week. After extraction the sample was filtered, evaporated to remove the residual solvent using a rotary evaporator (Heidolph VV 2000 , Germany) under reduced pressure at $40{ }^{\circ} \mathrm{C}$. The extract was reconstituted in $10 \mathrm{~mL}$ dimethylsulfoxide (DMSO) and stored at $-80^{\circ} \mathrm{C}$ till further use.

\subsection{Determination of major phytochemicals in prepared extract}

\subsubsection{Determination of total phenolic content}

The total phenolic content was determined according to the FolinCiocalteu procedure[39]. Total phenolics content was expressed as $\mathrm{mg} / \mathrm{g}$ gallic acid equivalent using a derived equation from the calibration curve: $\mathrm{Y}=0.034 \mathrm{x}+0.111, \mathrm{R}^{2}=0.999$, where $\mathrm{x}$ is the absorbance and $\mathrm{Y}$ is the gallic acid equivalent $(\mathrm{mg} / \mathrm{g})$.

\subsubsection{Determination of total flavonoid content}

The total flavonoids content was determined according to Zilic et al.[39] using aluminum chloride $\left(\mathrm{AlCl}_{3}\right)$ colorimetric assay. Total flavonoids content was calculated as catechin equivalent $(\mathrm{mg} / \mathrm{g})$ using the following equation from the calibration curve: $Y=0.012 x$ $+0.008, R^{2}=0.998$, where $\mathrm{x}$ is the absorbance and $\mathrm{Y}$ is the catechin equivalent $(\mathrm{mg} / \mathrm{g})$.

\subsection{Determination of antioxidant activity of prepared extracts}

\subsubsection{Determination of DPPH radical scavenging activity}

Free radical scavenging capacity of extracts were determined using the stable DPPH according to Hwang and Do Thi[40]. The standard curve was prepared using Trolox $\left(\mathrm{Y}=2.441 \mathrm{x}+2.113, \mathrm{R}^{2}=0.999\right.$, where $\mathrm{x}$ is the inhibition $\%$ and $\mathrm{Y}$ is the trolox equivalent $\mathrm{mg} / \mathrm{g}$ ). 
Results were expressed as mg of Trolox equivalent per gram of extract.

\subsubsection{Determination of ABTS radical scavenging activity}

ABTS radical scavenging capacity of extract was determined according to Hwang and Do Thi[40]. The standard curve was prepared using Trolox $\left(\mathrm{Y}=2.965 \mathrm{x}+0.693, \mathrm{R}^{2}=0.999\right.$, where $\mathrm{x}$ is the inhibition $\%$ and $\mathrm{Y}$ is the trolox equivalent $\mathrm{mg} / \mathrm{g}$ ). Results were expressed as $\mathrm{mg}$ of Trolox equivalent per gram of extract.

\subsubsection{Ferric reducing activity power (FRAP) assay}

The FRAP assay was done according to Hwang and Do Thi[40]. The standard curve was prepared using Trolox $\left(\mathrm{Y}=0.041 \mathrm{x}+0.006, \mathrm{R}^{2}=\right.$ 0.999 , where $\mathrm{x}$ is the inhibition $\%$ and $\mathrm{Y}$ is the trolox equivalent $\mathrm{mg} /$ g). Results were expressed as mg of Trolox equivalent per gram of extract.

\subsection{Separation and identification of phenolic acids by High- performance liquid chromatography (HPLC)}

Samples were injected automatically into an HP 1100 series HPLC system (Hewlett-Packard, GmbH, Germany) equipped with a diode array detector (DAD). Absorption spectra for the main peaks were recorded at 280 and $320 \mathrm{~nm}$. The HPLC system was equipped with a Xterra RP18 reverse phase column $(4.6 \mathrm{~mm} \times 250 \mathrm{~mm})$ with a spherical particle size of $5 \mu \mathrm{m}$, which was kept at $25^{\circ} \mathrm{C}$. The mobile phase was composed of $1 \%$ formic acid (A) and acetonitrile (B), and the elution gradient was 2 to $100 \%$ (B) in $40 \mathrm{~min}$ at a flow rate of 0.5 $\mathrm{mL} / \mathrm{min}$ and $25{ }^{\circ} \mathrm{C}$. The injection volume was $20 \mu \mathrm{L}[41]$.

\subsection{Animals management and semen collection}

Twenty sexually mature and fertile New Zealand White (NZW) male rabbits were obtained from the same herd in a commercial farm, for the purpose of this study. Rabbits aged 26-30 wk and weighing 2.3-2.9 kg. Bucks were individually housed in metal wire mesh cages provided with separate facilities for feeding and water supply. All bucks were fed a commercial diet and provided with food and water ad libitum.

Rabbit Bucks were trained to mount teaser female and then ejaculated in artificial vagina (IMV, France) adapted at $40-42{ }^{\circ} \mathrm{C}$. Semen was collected twice weekly. Each ejaculate was assessed for initial semen quality; only those that were white, $>200 \mu \mathrm{L}$ in volume, $\geq 300 \times 10^{6}$ cells $/ \mathrm{mL}$ in concentration and with $\geq 70 \%$ motile spermatozoa were included in the study.

\subsection{Experimental design}

\subsubsection{Pilot experiment for selection of useful extract concentrations}

(1) After semen collection, selected ejaculates were immediately pooled to avoid individual differences and to obtain sufficient volume for each treatment. (2) The pooled samples were divided into 11 aliquots (each of $500 \mu \mathrm{L}$ ). (3) The first aliquot was diluted 1:10 in Tris-citrate-glucose (TCG) basic extender (250 mM Trishydroxymethylaminomethane, $88 \mathrm{mM}$ citric acid, $47 \mathrm{mM}$ glucose[1]. Three percent egg yolk was added to the basic extender as a modification (TCGY). (4) The other 10 aliquots were diluted 1:10 in the TCGY basic extender enriched with ten concentrations of PEE as shown in Table 1.

Table 1

Sperm motility percentages (Mean \pm SE) of rabbit semen after chilled storage in TCG extenders enriched with different concentrations $(\mathrm{mg} / 5 \mathrm{ml}$ extender) of propolis ethanolic extract (PEE).

\begin{tabular}{lcccc}
\hline \multirow{2}{*}{$\begin{array}{l}\text { Concentration } \\
(\mathrm{mg} / 5 \mathrm{~mL})\end{array}$} & $2 \mathrm{~h}$ & $24 \mathrm{~h}$ & $48 \mathrm{~h}$ & $72 \mathrm{~h}$ \\
\cline { 2 - 5 } Control $(0.0)$ & $88.33^{\mathrm{B}} \pm 1.67$ & $73.33^{\mathrm{B}} \pm 1.67$ & $60.00^{\mathrm{B}} \pm 2.89$ & $33.33^{\mathrm{E}} \pm 1.67$ \\
0.4 & $87.50^{\mathrm{B}} \pm 1.45$ & $67.50^{\mathrm{C}} \pm 1.45$ & $47.50^{\mathrm{CD}} \pm 1.45$ & $32.50^{\mathrm{E}} \pm 1.45$ \\
$0.8^{*}$ & $87.50^{\mathrm{B}} \pm 1.45$ & $72.50^{\mathrm{B}} \pm 1.45$ & $57.50^{\mathrm{B}} \pm 1.45$ & $42.50^{\mathrm{C}} \pm 1.45$ \\
$1.2^{*}$ & $92.50^{\mathrm{A}} \pm 1.45$ & $82.50^{\mathrm{A}} \pm 1.45$ & $67.50^{\mathrm{A}} \pm 1.45$ & $52.50^{\mathrm{B}} \pm 1.45$ \\
$1.6^{*}$ & $92.50^{\mathrm{A}} \pm 1.45$ & $82.50^{\mathrm{A}} \pm 1.45$ & $72.50^{\mathrm{A}} \pm 1.45$ & $57.50^{\mathrm{A}} \pm 1.45$ \\
$2.0^{*}$ & $92.50^{\mathrm{A}} \pm 1.45$ & $82.50^{\mathrm{A}} \pm 1.45$ & $67.50^{\mathrm{A}} \pm 1.45$ & $52.50^{\mathrm{B}} \pm 1.45$ \\
2.4 & $87.50^{\mathrm{B}} \pm 1.45$ & $67.50^{\mathrm{C}} \pm 1.45$ & $52.50^{\mathrm{C}} \pm 1.45$ & $37.50^{\mathrm{D}} \pm 1.45$ \\
2.8 & $87.50^{\mathrm{B}} \pm 1.45$ & $62.50^{\mathrm{D}} \pm 1.45$ & $47.50^{\mathrm{CD}} \pm 1.45$ & $32.50^{\mathrm{E}} \pm 1.45$ \\
3.2 & $82.50^{\mathrm{C}} \pm 1.45$ & $57.50^{\mathrm{E}} \pm 1.45$ & $42.50 \pm 1.45$ & $22.50^{\mathrm{F}} \pm 1.45$ \\
3.6 & $82.50^{\mathrm{C}} \pm 1.45$ & $57.50^{\mathrm{E}} \pm 1.45$ & $37.50^{\mathrm{E}} \pm 1.45$ & $20.00^{\mathrm{FG}} \pm 0.00$ \\
4.0 & $80.00^{\mathrm{C}} \pm 0.00$ & $52.50^{\mathrm{F}} \pm 1.45$ & $32.50^{\mathrm{F}} \pm 1.45$ & $17.50^{\mathrm{G}} \pm 1.45$ \\
$F$ & 9.28 & 54.10 & 64.16 & 95.10 \\
$P$ & 0.0001 & $0.000^{\circ} 1$ & 0.0001 & 0.0001 \\
\hline
\end{tabular}

Different superscripts (A, B.... etc) within the same column indicate significant difference using Waller Duncan K-ratio $(P<0.05)$. * Selected concentrations will be used in the experimental design.

\subsubsection{Experimental design to select the optimal extract enriched extender}

Immediately after semen collection, selected ejaculates were pooled so as to allow sufficient volume for each treatment. The pooled sample was splitted in five subsamples (each of $500 \mu \mathrm{L}$ ) to prepare one of the five treatments as follows: The first aliquot was diluted 1:10 in TCGY basic extender and served as control. The other four aliquots were diluted 1:10 in the TCGY extender supplemented with the selected 4 concentrations of the PEE that were obtained from the pilot experiment (Table 1).

\subsection{Semen evaluation}

The diluted semen samples were refrigerated in an incubator at $4{ }^{\circ} \mathrm{C}$ for $72 \mathrm{~h}$. Forward motility, sperm viability, sperm membrane integrity and acrosome integrity \% were assessed after 2, 24, 48 and $72 \mathrm{~h}$ post-chilling.

\subsubsection{Sperm motility}

A drop of semen was placed on a pre-warmed slide $\left(37^{\circ} \mathrm{C}\right)$ and covered with a cover slip. Sperm motility subjectively was assessed 
using a phase contrast hot stage microscope set at a magnification of $400 \times$ and equipped with a heating plate $\left(37^{\circ} \mathrm{C}\right)$.

\subsubsection{Sperm morphology and viability}

Stained smear was prepared as soon after ejaculation using an eosin nigrosine staining mixture at 1:4 dilution rate[42]. The principle of these techniques is dye exclusion as red eosin stains dead sperm head while nigrosine provides a blue-black background.

\subsubsection{Sperm membrane integrity: Hypo-osmotic swelling test (HOST)}

HOST is a relatively simple test developed for rabbit spermatozoa to evaluate the functional integrity of the spermatozoa membrane[43] against a hypo-osmotic solution of $60 \mathrm{mOsmol} / \mathrm{L}$. The swollen spermatozoa characterized by a coiled tail which is an indication on the sperm intact plasma membrane.

\subsubsection{Acrosome integrity}

In the present study, Giemsa was used to stain the acrosome dark purple. Staining technique[44] was as follow: (1) Fresh ejaculate was diluted at 1:5 in warm normal saline. (2) Diluted semen was smeared and air-dried. (3) Smear was fixed in $10 \%$ neutral formal saline for 15 min. (4) Fixed smear was washed in running water for 20 min. (5) Fixed smear was immersed in Giemsa working solution overnight. (6) Stained smear was rinsed in two changes of distilled water and air-dried. One hundred spermatozoa per sample were examined with an oil immersion at $1000 \times$ magnification for acrosome integrity in each stained smear.

\subsection{Statistical analysis}

Statistical analysis was analyzed using the SAS computerized program v. 9.2[45] to calculate the analysis of variance (ANOVA) for the different parameters between control and additives replications. Significant difference between means was calculated using Duncan multiple range test at $P<0.05$.

\section{Results}

\subsection{Total phenolic content, total flavonoids content, antioxidant activities and HPLC analysis of Propolis ethanolic extract}

Data revealed the presence of a considerable amount of total phenolic compounds $[(98.67 \pm 1.33) \mathrm{mg}$ GAE/g extract $]$ and total flavonoids $[(70.16 \pm 1.27) \mathrm{mg} \mathrm{CE} / \mathrm{g}$ extract] which are parallel to an antioxidant activity assessed as ABTS, DPPH and FRAP [(198.65 \pm 1.44$), 180.18 \pm 1.72)$ and $(306.17 \pm 3.83) \mathrm{mmol} / \mathrm{L} \mathrm{TE} / \mathrm{g}$ extract respectively]. This was interpreted by HPLC analysis against 24 standard metabolites (Table 2, Figure 1). The most effective compound in the prolopolis ethanolic extract was the chlorogenic acids represented in $36.906 \mathrm{mg} / \mathrm{g}$ extract. Other compounds were found in less amounts rosmarinic acid $(3.959 \mathrm{mg} / \mathrm{g}$ extract), myrcetin (1.946 mg/g extract), kaempferol (1.089 mg/g extract) and apeginin7-glucoside $(1.113 \mathrm{mg} / \mathrm{g}$ extract). There were further compounds lower than $1 \mathrm{mg} / \mathrm{g}$ extract as protochatchuic acid $(0.165 \mathrm{mg} / \mathrm{g}$ extract), ferulic acid $(0.131 \mathrm{mg} / \mathrm{g}$ extract $)$, quercetin $(0.271 \mathrm{mg} / \mathrm{g}$ extract), apeginin $(0.544 \mathrm{mg} / \mathrm{g}$ extract) (Figure 2$)$.

Table 2

HPLC analysis of polyphenolic compounds in propolis ethanolic extract (PEE).

\begin{tabular}{lrr}
\hline Compound & Retention Time (min) & $\begin{array}{c}\text { Concentration }(\mu \mathrm{g} / \mathrm{g} \\
\text { extract) }\end{array}$ \\
\hline Pyrogallol & 4.90 & 0.00 \\
Gallic acid & 5.90 & 0.00 \\
Protochatechuic acid & 10.03 & 164.96 \\
P-hydroxybenzoic acid & 15.22 & 0.00 \\
Catachine & 18.37 & 0.00 \\
Chlorogenic acid & 20.28 & 3606.00 \\
Caffeic acid & 21.08 & 0.00 \\
Syringic acid & 22.52 & 0.00 \\
Vanillic acid & 24.82 & 0.00 \\
Scoplatine & 31.07 & 0.00 \\
Ferulic acid & 32.17 & 131.15 \\
Sinapic acid & 33.56 & 0.00 \\
Rutin & 36.18 & 0.00 \\
P-coumaric acid & 36.95 & 0.00 \\
Naringeen & 38.07 & 0.00 \\
Hisperdin & 38.60 & 0.00 \\
Apeginin-7-glucoside & 38.96 & 1112.67 \\
Myrcetin & 40.24 & 1945.59 \\
Rosmarinic acid & 40.95 & 3959.41 \\
Cinnamic acid & 41.52 & 0.00 \\
Quercetin & 43.01 & 271.48 \\
Apegnin & 43.72 & 544.07 \\
Kaempferol & 46.22 & 1089.00 \\
Chyrsin & 52.24 & 0.00 \\
\hline & &
\end{tabular}

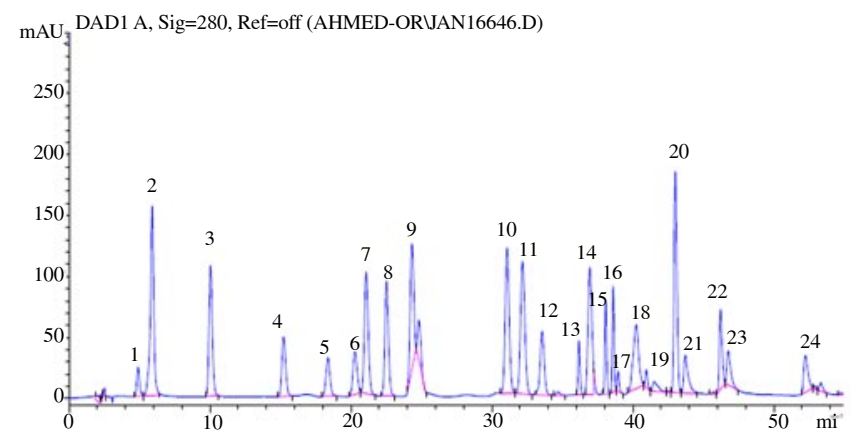

Figure 1. HPLC Chromatograms of standard metabolites showing signal from diode array detector at wavelength 280

Peak 1, Pyrogallol; 2, Gallic acid; 3, Protochatechuic acid; 4, P-hydroxybenzoic acid; 5, Catachine; 6, Chlorogenic acid; 7, Caffeic acid; 8. Syringic acid; 9, Vanillic acid; 10, Scoplatine; 11, ferulic acid; 12, Sinapic acid; 13, Rutin; 14, p-coumaric acid; 15, Naringeen; 16, Hisperdin; 17, Apeginin-7-glucoside; 18, Myrcetin; 19, Rosmarinic acid; 20, Cinnamic acid; 21, Quercetin; 22, Apegnin; 23, Kaempferol ; 24, Chyrsin. 
DAD1 A, Sig=280, Ref=off (AHMED-ORJAN16646.D)

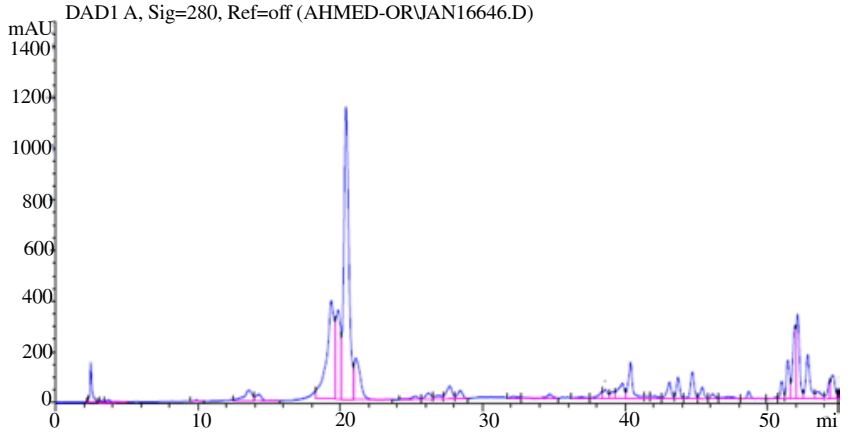

Figure 2. HPLC Chromatograms of propolis extract showing signal from diode array detector at wavelength 280 .

Peak 1, Protochatchuic acid; 2, Chlorogenic acid; 3, Ferulic acid; 4, Apeginin7-glucoside; 5, Myrcetin; 6, Rosmarinic acid; 7, Quercetin; 8, Apegnin; 9, Kaempferol

\subsection{Sperm motility percentage}

Data output in Table 3 showed that the chilling time had a regression effect which was significantly $(P<0.0001)$ represented by the gradual lowering of the overall mean of motile sperm from $94.58 \%$ after $2 \mathrm{~h}$ to $49.17 \%$ after $72 \mathrm{~h}$. This coincided the sperm motility\% within every treatment (within column) (control (0), 0.8, 1.2, 1.6 and $2.0 \mathrm{mg}$ PEE/5 mL tris extender) from 2 to $72 \mathrm{~h}$.

Concerning the enrichments of $5 \mathrm{~mL}$ tris extender with different concentrations of PEE within rows (Table 3), the concentrations of $1.2,1.6$ and $2.0 \mathrm{mg} \mathrm{PEE} / 5 \mathrm{~mL}$ tris extender were significantly $(P<0.0001)$ the best PEE enrichments that maintained higher motility\% from 2 to $72 \mathrm{~h}$ compared to the control (0 mg PEE) and the concentration of $0.8 \mathrm{mg} \mathrm{PEE} / 5 \mathrm{~mL}$ tris extender. This was approved by the analogous overall means with their respective concentrations.

\subsection{Sperm livability percentage}

Data output in Table 4 showed that the chilling time had a regression effect which was significantly $(P<0.0001)$ represented by the gradual lowering of the overall mean of live sperm percentage from $93.00 \%$ after 2 hours to $89.67 \%$ after $72 \mathrm{~h}$. This coincided the sperm livability \% within treatment (within columns) (control (0), 1.6 and $2.0 \mathrm{mg}$ PEE/5 $\mathrm{mL}$ tris extender) from 2 to $72 \mathrm{~h}$.

Concerning the enrichments of $5 \mathrm{~mL}$ tris extender with different concentrations of PEE (within rows) (Table 4), there is no significant difference between different concentrations of PEE compared to the control. This was approved by the analogous overall means with their respective concentrations.

\subsection{Sperm abnormality percentage}

Data output in Table 5 showed that the overall mean of abnormal sperm percentage was significantly $(P<0.0001)$ increased from $14.25 \%$ after $2 \mathrm{~h}$ to $17.67 \%$ after $72 \mathrm{~h}$. This coincided the sperm abnormality \% within treatment (within columns) (control (0), 0.8, 1.6 and $2.0 \mathrm{mg}$ PEE/5 mL tris extender) from 2 to $72 \mathrm{~h}$.

Concerning the enrichments of $5 \mathrm{~mL}$ tris extender with different concentrations of PEE (within rows) (Table 5), there is a significant $(P<0.0347)$ difference between the concentrations 1.2 and 1.6 of PEE in tris extender compared to the control after $72 \mathrm{~h}$. The overall mean of treatment with the concentrations 1.2 and 1.6 PEE in tris extender were significantly $(P<0.0010)$ different with the concentrations of 0.8 and 2.0 of PEE.

Table 3

Sperm motility percentages (Mean \pm SE) of rabbit semen after chilled storage in TCG extender enriched with different concentrations (mg/5 $\mathrm{ml}$ extender) of propolis ethanolic extract (PEE).

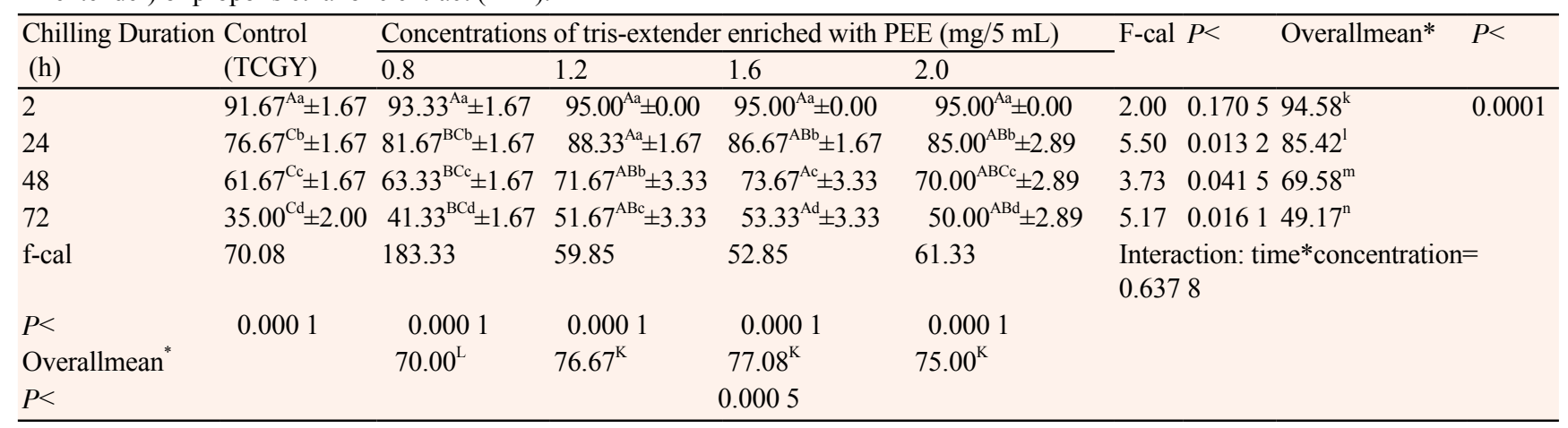

Overall mean concern the 2 way analysis without the control.

Different superscripts (A, B, C, D, E) within the same row indicate significant difference using Duncan's multiple range test $(P<0.05)$.

Different superscripts (a, b, c, d, e) within the same column indicate significant difference using Duncan's multiple range test $(P<0.05)$.

Different superscripts $(\mathrm{K}, \mathrm{L}, \mathrm{M}, \mathrm{N})$ of overall means within rows indicate significant difference using Duncan's multiple range test $(P<0.05)$.

Different superscripts $(\mathrm{k}, 1, \mathrm{~m}, \mathrm{n})$ of overall means within columns indicate significant difference using Duncan's multiple range test $(P<0.05)$. 


\subsection{Sperm membrane integrity percentage}

Data output in Table 6 showed that the overall mean of sperm membrane integrity (HOST) percentages was significantly $(P<0.0001)$ decreased from $74.08 \%$ after 2 h to $70.75 \%$ after 72 h. This coincided the Sperm membrane integrity $\%$ within treatment (within columns) (control (0) and $0.8 \mathrm{mg} \mathrm{PEE} / 5 \mathrm{ml}$ tris extender) from 2 to $72 \mathrm{~h}$.

Concerning the enrichments of $5 \mathrm{~mL}$ tris extender with different concentrations of PEE (within rows) (Table 6), there is a significant $(P<0.0001-P<0.0027)$ difference between the concentrations $0.8,1.2,1.6$ and 2.0 of PEE in tris extender compared to the control after 2, 24, 48 and $72 \mathrm{~h}$. The overall mean of treatment with the concentrations 1.2 and 1.6 PEE in tris ex;tender were significantly $(P<0.0035)$ different with the concentrations of 0.8 and 2.0 of PEE.

\subsection{Sperm acrosome integrity percentage}

Data output in Table 7 showed that the overall mean of sperm acrosome integrity percentages was significantly $(P<0.0001)$ decreased from $95.33 \%$ after $2 \mathrm{~h}$ to $93.00 \%$ after $72 \mathrm{~h}$. This coincided the Sperm acrosome integrity \% within treatment (within columns) (control (0) and $0.8 \mathrm{mg}$ PEE/5 mL tris extender) from 2 to $72 \mathrm{~h}$.

Concerning the enrichments of $5 \mathrm{~mL}$ tris extender with different concentrations of PEE (within rows) (Table 7), there is a significant $(P<0.0001-P<0.0159)$ difference between the concentrations 0.8 , 1.2, 1.6 and 2.0 of PEE in tris extender compared to the control after 2,48 and $72 \mathrm{~h}$. The overall mean of treatment was not significantly different between all the concentrations of PEE.

\section{Discussion}

A good semen quality is a main target requested from the male reproduction. This is in need for a physiological boundary of ROS to accomplish its role. Whereas, high levels of ROS is sticky related with the hindrance of sperm fertilizing capability[46]. The feed

Table 4

Sperm livability percentages (Mean \pm SE) of rabbit semen after chilled storage in TCG extender enriched with different concentrations (mg/5 $\mathrm{ml}$ extender) of propolis ethanolic extract (PEE).

\begin{tabular}{|c|c|c|c|c|c|c|c|c|c|}
\hline \multirow{2}{*}{$\begin{array}{l}\text { Chilling } \\
\text { duration (h) }\end{array}$} & \multirow{2}{*}{$\begin{array}{l}\text { Control } \\
\text { (TCGY) }\end{array}$} & \multicolumn{4}{|c|}{ Concentrations of tris-extender enriched with PEE $(\mathrm{mg} / 5 \mathrm{~mL})$} & \multirow[t]{2}{*}{ F-cal } & \multirow[t]{2}{*}{$P<$} & \multirow[t]{2}{*}{ Overall mean* } & \multirow[t]{2}{*}{$P<$} \\
\hline & & 0.8 & 1.2 & 1.6 & 2.0 & & & & \\
\hline 2 & $92.33^{\mathrm{Aa}} \pm 0.33$ & $92.67^{\mathrm{Aa}} \pm 0.33$ & $93.00^{\mathrm{Aa}} \pm 0.58$ & $93.33^{\mathrm{Aa}} \pm 0.33$ & $93.00^{\mathrm{Aa}} \pm 0.58$ & 0.72 & 0.5962 & $93.00^{k}$ & 0.0001 \\
\hline 24 & $90.67^{\mathrm{Aa}} \pm 0.67$ & $90.67^{\mathrm{Aab}} \pm 0.67$ & $91.67^{\mathrm{Aa}} \pm 0.88$ & $92.00^{\mathrm{Aab}} \pm 0.00$ & $91.33^{\mathrm{Aab}} \pm 0.67$ & 0.84 & 0.5293 & $91.42^{1}$ & \\
\hline 48 & $90.00^{\mathrm{Aab}} \pm 0.00$ & $90.00^{\mathrm{Ab}} \pm 1.15$ & $91.00^{\mathrm{Aa}} \pm 1.53$ & $91.33^{\mathrm{Aab}} \pm 0.67$ & $90.00^{\mathrm{Abc}} \pm 0.00$ & 0.53 & 0.7277 & $90.58^{\operatorname{lm}}$ & \\
\hline 72 & $88.00^{\mathrm{Ab}} \pm 1.15$ & $89.33^{\mathrm{Ab}} \pm 0.67$ & $90.00^{\mathrm{Aa}} \pm 1.15$ & $90.00^{\mathrm{Ab}} \pm 1.15$ & $89.33^{\mathrm{Ac}} \pm 0.67$ & 0.68 & 0.6203 & $89.67^{\mathrm{m}}$ & \\
\hline f-cal & 6.80 & 3.56 & 1.33 & 4.08 & 8.58 & \multicolumn{4}{|c|}{$\begin{array}{l}\text { Interaction: time } * \text { concentration }= \\
0.9995\end{array}$} \\
\hline$P<$ & 0.0136 & 0.0672 & 0.3322 & 0.0497 & 0.0070 & & & & \\
\hline Overall mean* & & $90.67^{\mathrm{K}}$ & $91.42^{\mathrm{K}}$ & $91.67^{\mathrm{K}}$ & $90.92^{\mathrm{K}}$ & & & & \\
\hline$P<$ & & & & .2900 & & & & & \\
\hline
\end{tabular}

Overall mean concern the 2 way analysis without the control.

Different superscripts (A, B, C, D, E) within the same row indicate significant difference using Duncan's multiple range test $(P<0.05)$.

Different superscripts (a, b, c, d, e) within the same column indicate significant difference using Duncan's multiple range test $(P<0.05)$.

Different superscripts $(\mathrm{K}, \mathrm{L}, \mathrm{M}, \mathrm{N})$ of overall means within rows indicate significant difference using Duncan's multiple range test $(P<0.05)$.

Different superscripts $(\mathrm{k}, 1, \mathrm{~m}, \mathrm{n})$ of overall means within columns indicate significant difference using Duncan's multiple range test $(P<0.05)$.

Table 5

Sperm abnormality percentages (Mean $\pm \mathrm{SE}$ ) of rabbit semen after chilled storage in TCG extender enriched with different concentrations ( $\mathrm{mg} / 5$ $\mathrm{ml}$ extender) of propolis ethanolic extract (PEE).

\begin{tabular}{|c|c|c|c|c|c|c|c|c|c|}
\hline \multirow{2}{*}{$\begin{array}{l}\text { Chilling } \\
\text { duration (h) }\end{array}$} & \multirow{2}{*}{$\begin{array}{l}\text { Control } \\
\text { (TCGY) }\end{array}$} & \multicolumn{4}{|c|}{ Concentrations of tris-extender enriched with PEE $(\mathrm{mg} / 5 \mathrm{~mL})$} & \multirow[t]{2}{*}{ F-cal } & \multirow[t]{2}{*}{$P<$} & \multirow[t]{2}{*}{ Overall mean* } & \multirow[t]{2}{*}{$P<$} \\
\hline & & 0.8 & 1.2 & 1.6 & 2.0 & & & & \\
\hline 2 & $14.00^{\mathrm{Ac}} \pm 0.58$ & $14.67^{\mathrm{Ab}} \pm 0.67$ & $14.00^{\mathrm{Aa}} \pm 0.58$ & $13.67^{\mathrm{Ab}} \pm 0.88$ & $14.67^{\mathrm{Ac}} \pm 0.33$ & 0.50 & 0.7368 & $14.25^{\mathrm{m}}$ & 0.0001 \\
\hline 24 & $17.00^{\mathrm{Ab}} \pm 1.00$ & $17.00^{\mathrm{Aab}} \pm 0.58$ & $15.00^{\mathrm{Aa}} \pm 0.58$ & $15.00^{\text {Aab }} \pm 0.58$ & $16.33^{\mathrm{Ab}} \pm 0.33$ & 2.42 & 0.1171 & $15.83^{1}$ & \\
\hline 48 & $18.00^{\mathrm{Aab}} \pm 0.58$ & $18.00^{\mathrm{Aa}} \pm 1.15$ & $15.67^{\mathrm{Aa}} \pm 1.33$ & $15.33^{\mathrm{Aab}} \pm 0.33$ & $16.67^{\mathrm{Ab}} \pm 0.33$ & 2.15 & 0.1486 & $16.42^{1}$ & \\
\hline 72 & $20.33^{\mathrm{Aa}} \pm 0.88$ & $19.00^{\mathrm{ABa}} \pm 0.58$ & $16.67^{\mathrm{Ba}} \pm 1.33$ & $16.67^{\mathrm{Ba}} \pm 0.33$ & $18.33^{\mathrm{ABa}} \pm 0.33$ & 3.98 & 0.0347 & $17.67^{\mathrm{k}}$ & \\
\hline f-cal & 11.27 & 5.64 & 1.19 & 4.56 & 20.33 & \multicolumn{4}{|c|}{$\begin{array}{l}\text { Interaction: time }{ }^{*} \text { concentration }= \\
0.9770\end{array}$} \\
\hline$P<$ & 0.0030 & 0.0226 & 0.3723 & 0.0384 & 0.0004 & & & & \\
\hline Overall mean* & & $17.17^{\mathrm{K}}$ & $15.33^{\mathrm{L}}$ & $15.17^{\mathrm{L}}$ & $16.50^{\mathrm{K}}$ & & & & \\
\hline$P<$ & & & & 0010 & & & & & \\
\hline
\end{tabular}

Overall mean concern the 2 way analysis without the control.

Different superscripts (A, B, C, D, E) within the same row indicate significant difference using Duncan's multiple range test $(P<0.05)$.

Different superscripts (a, b, c, d, e) within the same column indicate significant difference using Duncan's multiple range test $(P<0.05)$.

Different superscripts $(\mathrm{K}, \mathrm{L}, \mathrm{M}, \mathrm{N})$ of overall means within rows indicate significant difference using Duncan's multiple range test $(P<0.05)$.

Different superscripts $(\mathrm{k}, 1, \mathrm{~m}, \mathrm{n})$ of overall means within columns indicate significant difference using Duncan's multiple range test $(P<0.05)$. 
on natural products as prescribed in folk medicine improved the motility and fertilizing capability of sperm, through facing up to the ROS deteriorating effects, as they enclose in their folds polyphenolic compounds, minerals, vitamins, enzymes and other antioxidants that play a role in scavenging free radicals and up-regulate certain metal chelation reactions[47]. The chilling is one of the detrimental factors that induce the production of ROS in extended semen of rabbits[5,6]. Propolis was used in this study as a natural additive to semen extender owing to its high contents of polyphenolic compounds, vitamins, minerals and other antioxidants in addition to its antinflammatory, antibacterial, immunoregulatory and strong cytoprotective effect against some toxic stimuli[48-52].

The present results showed that the addition of 0.8-2.0 mg PEE/5 $\mathrm{mL}$ Tris extender had significantly maintained the sperm quality (motility, viability, membrane and acrosome integrity and lowered the sperm abnormality to its minimal attendance) in a good condition during chilling till $72 \mathrm{~h}$ compared to the control treatment. The safe and best effective concentrations of PEE in Tris based extender were trapped between 1.2-1.6 mg PEE/5 mL Tris extender. This was attributed mainly to the high content of chlorogenic acid (36.9 $\mathrm{mg} / \mathrm{g}$ extract) which has a potent reducing power against the lipid peroxidation of sperm membrane chilled for $72 \mathrm{~h}$. This coincided with the addition of chlorogenic acid to Beltsville extender for boar semen stored for $72 \mathrm{~h}$ at $15{ }^{\circ} \mathrm{C}[53]$. Whereas, the presence of some other phenolic compounds as rosmarinic acid (3.959 $\mathrm{mg} / \mathrm{g}$ extract), myricetin (1.946 mg/g extract), Kaempferol (1.089 mg/g extract) and apeginin-7-glucoside $(1.113 \mathrm{mg} / \mathrm{g}$ extract) that have scavenging antioxidant activity against free radicals interpret the benefit beyond the enrichment of rabbit semen tris-based extender to overcome the lipid peroxidation process induced via chilling period[54-59]. This elongates the period of chilling in rabbit extended semen above 72 $\mathrm{h}$ in agreement with Di Lorio et al.[9] and Johinke et al.[10]. On the

Table 6

Sperm membrane integrity percentages (HOST) (Mean \pm SE) of rabbit semen after chilled storage in TCG extender enriched with different concentrations ( $\mathrm{mg} / 5 \mathrm{ml}$ extender) of propolis ethanolic extract (PEE).

\begin{tabular}{|c|c|c|c|c|c|c|c|c|c|}
\hline \multirow{2}{*}{$\begin{array}{l}\text { Chilling } \\
\text { Duration (h) }\end{array}$} & \multirow{2}{*}{$\begin{array}{l}\text { Control } \\
\text { (TCGY) }\end{array}$} & \multicolumn{4}{|c|}{ Concentrations of tris-extender enriched with PEE $(\mathrm{mg} / 5 \mathrm{~mL})$} & \multirow[t]{2}{*}{ F-cal } & \multirow[t]{2}{*}{$P<$} & \multirow[t]{2}{*}{ Overall mean* } & \multirow[t]{2}{*}{$P<$} \\
\hline & & 0.8 & 1.2 & 1.6 & 2.0 & & & & \\
\hline 2 & $67.67^{\mathrm{Ba}} \pm 1.45$ & $72.67^{\mathrm{Aa}} \pm 0.33$ & $75.00^{\mathrm{Aa}} \pm 1.00$ & $75.33^{\mathrm{Aa}} \pm 1.45$ & $73.33^{\mathrm{Aa}} \pm 0.33$ & 8.70 & 0.0027 & $74.08^{\mathrm{k}}$ & 0.0001 \\
\hline 24 & $64.00^{\mathrm{Ca}} \pm 1.00$ & $70.67^{\mathrm{Bab}} \pm 0.67$ & $73.33^{\mathrm{Aab}} \pm 0.67$ & $73.00^{\mathrm{Aab}} \pm 0.58$ & $72.33^{\mathrm{ABab}} \pm 0.33$ & 32.02 & 0.0001 & $72.33^{1}$ & \\
\hline 48 & $61.00^{\mathrm{Bab}} \pm 2.08$ & $71.33^{\text {Aab }} \pm 0.67$ & $72.33^{\mathrm{Aab}} \pm 1.20$ & $71.67^{\mathrm{Ab}} \pm 0.88$ & $71.67^{\mathrm{Aab}} \pm 0.88$ & 14.94 & 0.0003 & $71.75^{\mathrm{Im}}$ & \\
\hline 72 & $55.00^{\mathrm{Bb}} \pm 2.89$ & $69.33^{\mathrm{Ab}} \pm 0.67$ & $71.67^{\mathrm{Ab}} \pm 0.88$ & $71.33^{\mathrm{Ab}} \pm 0.67$ & $70.67^{\mathrm{Ab}} \pm 0.67$ & 24.13 & 0.0001 & $70.75^{\mathrm{m}}$ & \\
\hline f-cal & 7.27 & 5.33 & 2.29 & 3.60 & 3.49 & \multicolumn{4}{|c|}{$\begin{array}{l}\text { Interaction: time } * \text { concentration }= \\
0.9272\end{array}$} \\
\hline$P<$ & 0.0113 & 0.0260 & 0.1548 & 0.0656 & 0.0700 & & & & \\
\hline Overall mean & & $71.00^{\mathrm{L}}$ & $73.08^{\mathrm{K}}$ & $72.83^{\mathrm{K}}$ & $72.00^{\mathrm{KL}}$ & & & & \\
\hline$P<$ & & & & 035 & & & & & \\
\hline
\end{tabular}

Overall mean concern the 2 way analysis without the control.

Different superscripts (A, B, C, D, E) within the same row indicate significant difference using Duncan's multiple range test $(P<0.05)$.

Different superscripts (a, b, c, d, e) within the same column indicate significant difference using Duncan's multiple range test $(P<0.05)$

Different superscripts $(\mathrm{K}, \mathrm{L}, \mathrm{M}, \mathrm{N})$ of overall means within rows indicate significant difference using Duncan's multiple range test $(P<0.05)$.

Different superscripts $(\mathrm{k}, 1, \mathrm{~m}, \mathrm{n})$ of overall means within columns indicate significant difference using Duncan's multiple range test $(P<0.05)$.

Table 7

Sperm acrosome integrity percentages (Mean \pm SE) of rabbit semen after chilled storage in TCG extender enriched with different concentrations ( $\mathrm{mg} / 5 \mathrm{ml}$ extender) of propolis ethanolic extract (PEE).

\begin{tabular}{|c|c|c|c|c|c|c|c|c|c|}
\hline \multirow{2}{*}{$\begin{array}{l}\text { Chilling } \\
\text { duration (h) }\end{array}$} & \multirow{2}{*}{$\begin{array}{l}\text { Control } \\
(\mathrm{TCGY})\end{array}$} & \multicolumn{4}{|c|}{ Concentrations of tris-extender enriched with PEE $(\mathrm{mg} / 5 \mathrm{~mL})$} & \multirow{2}{*}{\multicolumn{2}{|c|}{ F-cal $\quad P<$}} & \multirow[t]{2}{*}{ Overall mean* } & \multirow[t]{2}{*}{$P<$} \\
\hline & & 0.8 & 1.2 & 1.6 & 2.0 & & & & \\
\hline 2 & $92.33^{\mathrm{Ba}} \pm 0.33$ & $95.00^{\mathrm{Aa}} \pm 0.58$ & $95.67^{\mathrm{Aa}} \pm 0.88$ & $96.00^{\mathrm{Aa}} \pm 0.58$ & $94.67^{\mathrm{Aa}} \pm 0.33$ & 6.23 & 0.0088 & $95.33^{\mathrm{k}}$ & 0.0001 \\
\hline 24 & $93.00^{\mathrm{Aa}} \pm 0.58$ & $94.00^{\mathrm{Aa}} \pm 0.58$ & $94.33^{\mathrm{Aa}} \pm 0.88$ & $94.33^{\mathrm{Aab}} \pm 0.67$ & $94.00^{\mathrm{Aab}} \pm 0.58$ & 0.67 & 0.6244 & $94.17^{1}$ & \\
\hline 48 & $90.67^{\mathrm{Bb}} \pm 0.67$ & $93.67^{\text {Aab }} \pm 0.33$ & $93.33^{\mathrm{Aa}} \pm 0.8$ & $94.67^{\mathrm{Aab}} \pm 0.67$ & $93.00^{\mathrm{Aab}} \pm 0.58$ & 5.18 & 0.0159 & $93.67^{1 \mathrm{~m}}$ & \\
\hline 72 & $88.00^{\mathrm{Bc}} \pm 0.00$ & $92.33^{\mathrm{Ab}} \pm 0.33$ & $93.33^{\mathrm{Aa}} \pm 0.67$ & $93.67^{\mathrm{Ab}} \pm 0.67$ & $92.67^{\mathrm{Ab}} \pm 0.67$ & 18.27 & 0.0001 & $93.00^{\mathrm{m}}$ & \\
\hline f-cal & 22.33 & 5.46 & 1.76 & 2.31 & 2.76 & \multicolumn{4}{|c|}{$\begin{array}{l}\text { Interaction: time } * \text { concentration }= \\
0.9714\end{array}$} \\
\hline$P<$ & 0.0003 & 0.0245 & 0.2323 & 0.1528 & 0.1117 & & & & \\
\hline $\begin{array}{l}\text { Overall } \\
\text { mean* }\end{array}$ & & $93.75^{\mathrm{K}}$ & $94.17^{\mathrm{K}}$ & $94.67^{\mathrm{K}}$ & $93.58^{\mathrm{K}}$ & & & & \\
\hline$P<$ & \multicolumn{5}{|c|}{0.0979} & & & & \\
\hline
\end{tabular}

Overall mean concern the 2 way analysis without the control.

Different superscripts (A, B, C, D, E) within the same row indicate significant difference using Duncan's multiple range test $(P<0.05)$.

Different superscripts $(\mathrm{a}, \mathrm{b}, \mathrm{c}, \mathrm{d}, \mathrm{e})$ within the same column indicate significant difference using Duncan's multiple range test $(P<0.05)$.

Different superscripts $(\mathrm{K}, \mathrm{L}, \mathrm{M}, \mathrm{N})$ of overall means within rows indicate significant difference using Duncan's multiple range test $(P<0.05)$.

Different superscripts $(\mathrm{k}, 1, \mathrm{~m}, \mathrm{n})$ of overall means within columns indicate significant difference using Duncan's multiple range test $(P<0.05)$ 
contrary, El-Nattat et al.[60] had used an antioxidant (L-carnitin) in rabbit semen tris-extender that doesn't exceed the $48 \mathrm{~h}$ chilling, while the incorporation of L-carnitine in the Galap (commercial extender, IMV, France) extended the chilling period to $72 \mathrm{~h}$. In conclusion, the enrichment of rabbit semen tris-basic extender with (1.2-1.6) $\mathrm{mg}$ PEE/5 mL tris-extender (as the best and safe concentrations) maintain the sperm characteristics in good condition all over $72 \mathrm{~h}$ of chilling.

\section{Acknowledgments}

The authors are greatly indebted to the National Research Centre for sponsoring this work through the project 12/1/14.

\section{Conflict of interest statement}

The authors declare that they have no conflict of interest.

\section{References}

[1] Roca J, Martínez S, Vázquez JM, Lucas X, Parrilla I, Martínez EA. Viability and fertility of rabbit spermatozoa diluted in Tris-buffer extenders and stored at $15{ }^{\circ} \mathrm{C}$. Anim Reprod Sci 2000; 64: 103-112.

[2] Nagy S, Sinkovics G, Kovács A. Viability and acrosome integrity of rabbit spermatozoa processed in a gelatin-supplemented extender. Anim Reprod Sci 2002; 70: 283-286.

[3] López-Gatius F, Sances G, Sancho M, Yániz J, Santolaria P, Gutiérrez $\mathrm{R}$, et al. Effect of solid storage at $15{ }^{\circ} \mathrm{C}$ onthe subsequent motility and fertility of rabbit semen. Theriogenology 2005; 64: 252-260.

[4] Aksoy M, Cankat Lehimcio lu N, Akman O. Effect of seminal plasma on functional integrity of rabbit sperm membranes during storage at $4{ }^{\circ} \mathrm{C}$ or freezing. Wrld Rabbit Sci 2008; 16: 1-6.

[5] Iaffaldano N, Rosato MP, Paventi G, Pizzuto R, Gambacorta M, Manchisi A. The irradiation of rabbit sperm cells with He-Ne laser prevents there in vitro liquid storage dependent damage. Anim Reprod Sci 2010; 119: 123-129.

[6] Rosato MP, Iaffaldano N. Effect of chilling temperature on the long-term survival of rabbit spermatozoa held either in a Tris-based or a jellified extender. Reprod Domest Anim 2011; 46: 301-308.

[7] Rosato MP, Di Iorio M, Manchisi A, Gambacorta M, Petrosino G, Centoducati G, Santacroce MP, et al. In vitro survivaland lipid peroxidation status of rabbit spermatozoa after both chilledand frozen storage in lycopene enriched extenders. Livest Sci 2012; 146: 199-202.

[8] Rosato MP, Iaffaldano N. Cryopreservation of rabbit semen: Comparing the effects of different cryoprotectants, cryoprotectant-free vitrification, and the use of albumin plus osmoprotectants on sperm survival and fertility after standard vapor freezing and vitrification. Theriogenology 2013; 79: 508-516.

[9] Michele Di I, Manchisi A, Rocco M, Chrenek P, Iaffaldano N. Comparison of different extenders on the preservability of rabbit semen stored at $5{ }^{\circ} \mathrm{C}$ for 72 hours. Ital J Anim Sci 2014; 13: 710-714.
[10]Johinke D, Graaf SP de, Bathgate R. investigation of in vitro parameters and in vivo fertility of rabbit spermatozoa after chilled storage. Anim Reprod Sci 2014; 147: 135-143.

[11]Moce' E, Vicente JS. Rabbit sperm cryopreservation: A review. Anim Reprod Sci 2009; 110: 1-24.

[12]Bansal AK, Bilaspuri GS. Impacts of oxidative stress and antioxidants on semen functions. Vet Med Int; 2011. doi: 10.4061/2011/686137 . [Online] Available from: http://dx.doi.org/10.4061/2011/686137.

[13]Kim S, Lee YJ, Kim YJ. Changes in sperm membrane and ROS following cryopreservation of liquid boar semen stored at $15{ }^{\circ} \mathrm{C}$. Anim Reprod Sci $2011 ; 124 ; 118-124$.

[14]Aviram M, Dornfield L, Rosenblatt M, Volkova N, Kaplan M, Coleman R. Pomegranate juice consumption reduces oxidative stress, atherogenic modifications to LDL, and platelet aggregation: Studies in humans and in atherosclerotic apolipoprotein E-deficient mice. Am J Clin Nutr 2000; 71: 1062-1076.

[15]Aviram M, Rosenblatt M, Gaitani D, Nitecki S, Hoffman A, Dornfield L. Pomegranate juice consumption for 3 years by patients with carotid artery stenosis (CAS) reduces common carotid intima-media thickness (IMT), blood pressure and LDL oxidation. Clin Nutr 2004; 23: 423-433.

[16]Sansone G, Nastri MJF, Fabbrocini A. Storage of buffalo (Bubalus bubalis) semen. Anim Reprod Sci 2000; 62: 55-76.

[17]El-Sheshtawy RI, El-Sisy GA, El-Nattat WS. Effects of pomegranate juice in Tris-based extender on cattle semen quality after chilling and cryopreservation. Asian Pac J Reprod 2016; 5(4): 335-339

[18]El-Nattat WS, El-Sheshtawy RI, El-Batawy KA, Shahba MI, El-Seadawy IE. Preservability of buffalo bull semen in tris-citrate extender enriched with bee's honey. J Innov Pharmaceut Biol Sci 2016; 3(1): 180-185.

[19]Seeram NP, Adams LS, Henning SM, Niu Y, Zhang Y, Muraleedharan $\mathrm{G}$, et al. In vitro antiproliferative, apoptotic and antioxidant activities of punicalagin, ellagic acid and a total pomegranate tannin extract are enhanced in combination with other polyphenols as found in pomegranate juice. J Nutr Biochem 2005; 16(6): 360-367.

[20]Tezcan F, Ozguven MG, Diken T, Ozcelik B, Erim FB. Antioxidant activity and total phenolic, organic acid and sugar content in commercial pomegranate juices. Food Chem 2009; 115: 873-877.

[21]Dantas CG, Nunes TLGM, Nunes TLGM, da Paixão AO, Reis FP, Júnior WDL, et al. Pharmacological evaluation of bee venom and melittin. Rev Bras Farmacogn 2014; 24: 67-72.

[22]Bastos EMAF, Simone M, Jorge DM, Soares AEE, Spivak M. In vitro study of the antimicrobial activity of Brazilian propolis against Paenibacillus larvae. J Invertebr Pathol 2008; 97: 273-281.

[23]Nassar SA, Mohamed AH, Soufy H, Nasr SM. Protective effects of Egyptian propolis against rabbit pasteurellosis. Biomed Res Int 2013. doi: 10.1155/2013/163724. [Online]Available from: http://dx.doi. org/10.1155/2013/163724.

[24]Murad JM, Calvi SA, Soares AMV, Bankova V, Sforcin JM. Effects of propolis from Brazil and Bulgaria on fungicidal activity of macrophages against Paracoccidioides Brasiliensis. J Ethnopharmacol 2002; 79: 331-334.

[25]Abd El Hady FK, Hegazi AG. Egyptian propolis: 8- Antiviral and antioxidant activities in relation to flavonoid content. The Global Meet on Veterinary Public Health \& Symposium on "New horizons in food security with special referrence to veterinary public health \& hygiene - 
Evolving strategies with global perspective", India 2008, .

[26]Rastrelli L. Activity of Cuba propolis extracts on Leishmania amazonensis and Trichomonas vaginalis. Nat Prod Commun 2011; 6: 973-976.

[27]Banskota AH, Tezuka Y, Kadota S. Recent progress in pharmacological research of propolis. Phytother Res 2001; 15: 561-571.

[28]Oršoli N, Baši I. Antitumor, hematostimulative and radioprotective action of water-soluble derivative of propolis (WSDP). Biomed Pharmacother 2005; 59: 561-570.

[29]Nassar SA, Mohamed AH, Soufy H, Nasr SM, Mahran KM. Immunostimulant effect of Egyptian propolis in rabbits. Sci World $J$ 2012. doi: 10.1100/2012/901516. [Online]Available from: http://dx.doi. org/10.1100/2012/901516.

[30]Ahn MR, Kumazawa S, Usui Y, Nakamura J, Matsuka M, Zhu F, et al. Antioxidant activity and constituents of propolis collected in various areas of China. Food Chem 2007; 101: 1383-1392.

[31]Atta AH, Nasr SM, Mouneir SM, Abdel-Aziem SH, Nassar SA. Egyptian propolis alleviates gentamicin induced nephrotoxicity in rats. J Adv Chem 2014; 6: 1109-1119.

[32]Zhang H, Wang G, Beta T, Dong J. Inhibitory properties of aqueous ethanolextracts of propolis on alpha-glucosidase. Evid Based Complement Altern Med 2015. doi: 10.1155/2015/587383. [Online]Available from: http://dx.doi.org/10.1155/2015/587383

[33]Tikhonov AI, Mamontova INS. Production and study of a lyophilized phenolic polysaccharide preparation from propolis. Farmatsevtichnii Zhurnal 1987; 3: 67-68.

[34]Khalil ML. Biological activity of bee propolis in health and disease. Asian Pac J Cancer Prev 2006; 7: 22-31.

[35]Yousef MI, Salama AF. Propolis protection from reproductive toxicity caused by aluminium chloride in male rats. Food Chem Toxic 2009; 47: 1168-1175.

[36]Jasprica D, Mornar A, Debeljak Z, Smolcic-Bubalo A, Medic-Saric $\mathrm{M}$, Mayer L, et al. In vivo study of propolis supplementation effects on antioxidative status and red blood cells. J Ethnopharmacol 2007; 110: 548-554.

[37]Sobocanec S, Sverko V, Balog T, Saric A, Rusak G, Likic S, et al. Oxidant/antioxidant properties of Croatian native propolis. J Agric Food Chem 2006; 54: 8018-8026.

[38]Cvek J, Medic-Saric M, Jasprica I, Zubic S, Vitali D, Mornar A, et al. Optimization of an extraction procedure and chemical characterization of Croatian propolis tinctures. Phytochem Analysis 2007; 18: 451-459.

[39]Zilic S, Serpen A, Akillioglu G, Jankovic M, Gokmen V. Distributions of phenolic compounds, yellow pigments and oxidative enzymes in wheat grains and their relation to antioxidant capacity of bran and debranned flour. J Cereal Sci 2012; 56: 652-658.

[40]Hwang ES, Do Thi N. Effects of extraction and processing methods on antioxidant compound contents and radical scavenging activities of Laver (Porphyra tenera). Prev Nutr Food Sci 2014; 19: 40-48.

[41]Gayosso-García Sancho LE, Yahia EM, Gonz_alez-Aguilar GA. Identification and quantification of phenols, carotenoids, and vitamin $\mathrm{C}$ from papaya (Carica papaya L., cv. Maradol) fruit determined by HPLCDAD-MS/MS-ESI. Food Res Int 2011; 44(5): 1284-1291.

[42]Blom E. Sperm morphology with reference to bull infertility. Ludhiana,
India: First All-India Symp Anim Reprod; 1977.

[43]Amorim EAM, Torres CAA, Graham JK, Amorima LS, Santos LVL. The hypoosmotic swelling test in fresh rabbit spermatozoa. Anim Reprod $S c i$ 2009; 111: 338-343.

[44]Watson PF. Use of giemsa stain to detect changes in the acrosome of frozen ram spermatozoa. Vet Record 1975; 97: 12-15.

[45]SAS. Statistical analysis system: User' s guide v. 9.2. USA: Inst. Inc., Cary N.C.; 2008

[46]Capucho C, Sette R, de Souza Predes F, de Castro Monteiro J, Pigoso AA, Barbieri R, et al. Green Brazilian propolis effects on sperm count and epididymis morphology and oxidative stress. Food Chem Toxicol 2012; 50: 3956-3962.

[47]Virgili F, Marino M. Regulation of cellular signals from nutritional molecules: a specific role for phytochemicals, beyond antioxidant activity. Free Rad Biol Med 2008; 45: 1205-1216.

[48]Rizk SM, Zaki HF, Mina MA. Propolis attenuates doxorubicin-induced testicular toxicity in rats. Food Chem Toxicol 2014; 67: 176-186.

[49]Burdock GA. Review of the biological properties and toxicity of bee propolis (propolis). Food Chem Toxicol 1998; 36: 347-363.

[50]Bueno-Silva B, Alencar SM, Koo H, Ikegaki M, Silva GV, Napimoga $\mathrm{MH}$, et al. Anti-inflammatory and antimicrobial evaluation of neovestitol and vestitol isolated from Brazilian red propolis. J Agric Food Chem 2013; 61: 4546-4550

[51]Sönmez MF, Çilenk KT, Karabulut D, Ünalmı S, Deligönül E, Öztürk I, et al. Protective effects of propolis on methotrexate-induced testis injury in rat. Biomed Pharmacother 2016; 79: 44-51.

[52]Çilenk KT, Öztürk İ, Sönmez MF. Ameliorative effect of propolis on the cadmium-induced reproductive toxicity in male albino rats. Exp Mol Pathol 2016; 101: 207-213

[53]Pereira BA, Zangeronimo MG, de Sousa RV, Teles MC, Mendez MFB, Rocha LGP. Effet de l'acide chlorogénique sur la peroxydation lipidique et la capacité antioxydante du sperme de verrat. Journées Recherche Porcine 2014; 46: 293-294.

[54]Luño V, Gil L, Olaciregui M, González N, Jerez RA, de Blas I. Rosmarinic acid improves function and in vitro fertilising ability of boar sperm after cryopreservation. Cryobiology 2014; 69: 157-162.

[55]Johinke D, de Graaf SP, Bathgate R. Quercetin reduces the in vitro production of $\mathrm{H}_{2} \mathrm{O}_{2}$ during chilled storage of rabbit spermatozoa. Anim Reprod Sci 2014; 151: 208-219.

[56]Johinke D, de Graaf SP, Bathgate R. The effect of sperm concentration and storage vessel on quercetin-supplemented rabbit semen during chilled storage. Reprod Domest Anim 2015; 50: 567-573.

[57]Gibb Z, Butler TJ, Morris LHA, Maxwell WMC, Grupen CG. Quercetin improves the postthaw characteristics of cryopreserved sex-sorted and nonsorted stallion sperm. Theriogenology 2013; 79: 1001-1009.

[58] Li H, Li HB, Zhang M, Yan F, Zhang ZX, Li ZL. Effect of apigenin on the reproductive system in male mice. Health 2010; 2(5): 435-440.

[59]Castilho EF, Guimarães JD, Martins LF, Pinho RO, Guimarães SEF, Espeschit CJB. Use of propolis and ascorbic acid on goat semen cryopreservation. Revista Brasileira de Zootecnia 2009; 38(12): 2335 2345 .

[60]El-Nattat WS, El-Sheshtawy RI, Mohamed AA. Effect of L-Carnitine on Semen Characteristics of Chilled Rabbit Semen. Global J Biotech Biochem 2011; 6(1): 8-12. 